Journal of Animal and Veterinary Advances 9 (4): 688-695, 2010

ISSN: $1680-5593$

(C) Medwell Journals, 2010

\title{
Effects of Parity, Days in Milk, Milk Production and Milk Components on Milk Urea Nitrogen in Chinese Holstein
}

\author{
${ }^{1}$ Zhijun Cao, ${ }^{1}$ Wenming Huang, ${ }^{2}$ Tian. Wang, ${ }^{3}$ Yu Wang, ${ }^{3}$ Wan Wen, ${ }^{1}$ Mei Ma and ${ }^{1}$ Shengli Li \\ ${ }^{1}$ State Key Laboratory of Animal Nutrition, College of Animal Science and Technology, \\ China Agricultural University, Beijing, 100193, China \\ ${ }^{2}$ College of Animal Science and Technology, Nanjing Agricultural University, Nanjing 210095, China \\ ${ }^{3}$ Ningxia Animal Husbandry Workstation, Yinchuan 750004, China
}

\begin{abstract}
The objectives of this study were to evaluate the effects of parity, Days in Milk (DIM), milk production and components on Milk Urea Nitrogen (MUN) concentration in Chinese Holstein. About 6500 lactating cows of 20 dairy farms from Ningxia, Shanghai and Beijing participated in this study. Finally, 29414 records from Jan 2008-July 2009 were analyzed. The milk components and MUN concentration were measured using a Fossomatic 4000 Milkoscan Analyzer at the Shanghai Milk Quality Laboratory. The mean MUN concentration was $19.4 \mathrm{mg} \mathrm{dL}-1$ and the lowest value appeared in the third and greater lactation. The concentration of MUN reached the highest at 90-120 DIM and began to go down approximately 120 DIM. A positive relationship existed between MUN and milk production, while negative relationship with milk protein and milk fat percentage were observed. Based on the results from this study, MUN concentration should be interpreted in association with parity, DIM, milk production and composition when MUN was regarded as a management tool to evaluate the efficiency of nitrogen utilization for dairy cows in China.
\end{abstract}

Key words: Parity, milk urea nitrogen, milk production, components, dairy cows

\section{INTRODUCTION}

Milk Urea Nitrogen (MUN) has been regardayed as an indicator of the efficiency of nitrogen utilization for dairy cows (Hof et al., 1997; Roseler et al., 1993; Schepers and Meijer, 1998; Wattiaux and Karg, 2004a) and MUN has also been investigated as a predictor of nitrogen output to the environment (Jonker et al., 1998; Wattiaux and Karg, 2004b).

Due to the advances in Infrared (IR) spectrophotometric methods for determining MUN concentration, many Dairy Herd Improvement (DHI) laboratories have adopted the rapid and inexpensive technology as an additional service to the farmers. A dairy performance-testing program was begun in China in the 1990s with the support of the Sino-Canada Integrated Dairy Cattle Breeding Program and the Sino-Japan Dairy Technical Cooperation Project (Miglior et al., 2009). Recently, MUN concentration has been added to DHI report in several laboratories in China.

In fact, many of the farmers and researchers may fail to see the importance of MUN concentration. The relationship between MUN and production variables has been evaluated by some studies. But the results were inconsistent. For example, some studies reported that there was a positive but nonlinear association between MUN and milk production (Kung and Huber, 1983; Carlsson et al., 1995; Godden and Kelton, 2001; Johnson and Young, 2003). However, negative association (Ismail et al., 1996) or no relationship (Baker et al., 1995; Carroll et al., 1988) had also been reported. Also, Johnson and Young (2003) reported there was positive, nonlinear relationship between MUN and milk protein percentage, while some studies reported that there was either no relationship between milk protein percentage and MUN (Broderick and Clayton, 1997) or a negative, nonlinear association (Godden and Kelton, 2001). As a result, a measure of the non nutritional factors affecting MUN is needed to investigate these associations.

It would be helpful for the farmers to improve the nitrogen utilization efficiency, when cows were fed in different forage categories and housing facilities. In some Provinces, such as Ningxia, rice straw was also fed to cows in mid and late lactation. The hypothesis was that MUN concentration might have different regularities

Corresponding Author: Shengli Li, State Key Laboratory of Animal Nutrition, College of Animal Science and Technology, China Agricultural University, Beijing, China 100193 
compared with previous studies. The objectives of this study were to evaluate the relationships between MUN and parity, Days in Milk (DIM), milk production and milk component, when using an IR test for measuring MUN.

\section{MATERIALS AND METHODS}

Data collection: The database used in this study was obtained from 3 Provinces (Ningxia, Shanghai and Beijing) from Jan 2008-July 2009. All of milk samples were collected during regular monthly DHI analysis. Laboratory measurements were performed by Shanghai Milk Quality Laboratory, using the combiFoss 4000 (Foss Electric, Hillerød, Denmark). Fat-Corrected Milk (FCM) yield was calculated with the Gaines' formula $\left(4 \%\right.$ FCM, $\mathrm{kg}$ day $^{-1}=0.4 \times$ milk, $\mathrm{kg} \mathrm{day}^{-1}+15 \times$ fat, $\mathrm{kg}$ day $^{-1}$; NRC 2001). Standard of data elimination is shown in Table 1. Herds removed from the study were those with unknown sample type (i.e., uncertain sampling time) or a small number of cows $(<5)$. Records DIM $>730$ (i.e., a lactation $>2$ years) were considered extreme and removed from the study and categories of $\leq 3.0$ and $>100.0 \mathrm{~kg}$ of milk were deleted. Herd management data (milking frequency, housing, feeding method, forage categories and diet composition) were collected through the researchers' farm visiting and questionnaire from producers. Finally, the database used for analysis included 29414 records from 6500 individual cows distributed in 20 herds.

Statistical analysis: The categories of DIM and MUN were similar to Johnson and Young (2003). Days in milk were grouped into 30 days increments, with those $>450$ days grouped into one category.

The concentration of MUN was grouped by increments of $2.0 \mathrm{mg} \mathrm{dL}^{-1}$ with those less than or equal to $6.0 \mathrm{mg} \mathrm{dL}^{-1}$ grouped into one category and those equal to or greater than $36.0 \mathrm{mg} \mathrm{dL} \mathrm{dL}^{-1}$ grouped into one category. Milk production was grouped by increments of $5.0 \mathrm{~kg} \mathrm{day}^{-1}$ with the upper grouping for cows of $45.0 \mathrm{~kg}$ milk protein percentage was grouped into categories

Table 1: Data set selection criteria

\begin{tabular}{|c|c|c|c|}
\hline $\begin{array}{l}\text { Test-day data file } \\
\text { (monthly records) }\end{array}$ & 30756 & Records deleted & $\begin{array}{l}\text { Records } \\
\text { remaining }\end{array}$ \\
\hline Missing data & - & 387 & 30369 \\
\hline Parity & $1-7$ & 327 & 30042 \\
\hline DIM & $0-730$ & 60 & 29982 \\
\hline Milk y ield (kg) & $3.0-100.0$ & 272 & 29710 \\
\hline Milk protein $(\%)$ & $0.25-9.5$ & 1 & 29709 \\
\hline Milk fat $(\%)$ & $0.25-9.5$ & 39 & 29670 \\
\hline Milk lactose (\%) & $0.25-9.5$ & 0 & 29670 \\
\hline $\mathrm{SCC}, \times 1000 \mathrm{~mL}^{-1}$ & $<10000$ & 79 & 29591 \\
\hline MUN (mg dL $\left.{ }^{-1}\right)$ & $0.1-39.5 \mathrm{mg} \mathrm{dL}^{-1}$ & 177 & 29414 \\
\hline
\end{tabular}

in two different ways. In one way, milk protein percentage was categorized into increments of $0.2 \%$ beginning with $2.4 \%$ and ending with $4.4 \%$. In the other way, milk protein categories were created with $\leq 3.0$, $3.01-3.2$ and $>3.2 \%$ based on the groupings in Nelson (1996).

Descriptive statistics were calculated for parity, DIM, MUN, milk yield and composition using the Proc Freq procedure of SPSS 12.0 (SPSS Inc., Chicago). Simple correlation coefficients and principal component analysis were calculated to determine collinearity. Multivariate mixed linear regression models using the Proc Mixed procedure in SPSS 12.0 (SPSS Inc., Chicago) were used to determine the association between MUN (independent variable) and parity, DIM, MUN, milk yield and composition (dependent variables). Significance was declared at $\mathrm{p} \leq 0.05$. A trend was considered to exist if $0.05<\mathrm{p} \leq 0.10$. All reported values were least square means unless otherwise stated.

\section{RESULTS AND DISCUSSION}

Characterization of database: In total, 20 herds were included in this study. Of these, $13(65 \%)$ were tie-stall facilities and $7(35 \%)$ were free-stall facilities. 14 herds $(70 \%)$ were fed a TMR, while the remaining 6 herds $(30 \%)$ were fed a separate ingredient. Corn silage and sheep grass (Leymus chinensis) were the predominant forages. Some rice straw was also fed to cows in mid and late lactation. Descriptive statistics for parity, DIM, milk production and components is shown in Table 2. The mean parity was 2.4 lactations and was similar to what was reported by Godden and Kelton (2001) and Johnson and Young (2003). Mean DIM was 204, which was higher than reported in other studies (Jonker et al., 1998; Godden and Kelton, 2001; Johnson and Young, 2003). The FCM yield was $21.7 \mathrm{~kg} \mathrm{day}^{-1}$, which was lower than reported in other MUN studies (Carlsson et al., 1995; Godden and Lissemore, 2001; Johnson and Young, 2003). Mean milk fat and protein percentage was 3.74 and $3.28 \%$, respectively. Mean MUN concentrations on cow-level

Table 2: Description of least squares means and SD of DHI variables $(n=29414)$

\begin{tabular}{|c|c|c|c|}
\hline Parameters & Mean \pm SD & Min. & Max. \\
\hline Parity & $2.4 \pm 1.50$ & 1.00 & 7.00 \\
\hline DIM (day) & $204.0 \pm 130.00$ & 2.00 & 730.00 \\
\hline Milk y ield (kg) & $22.7 \pm 8.90$ & 3.00 & 60.00 \\
\hline $\mathrm{FCM}(\mathrm{kg})$ & $21.7 \pm 8.90$ & 1.80 & 69.60 \\
\hline Milk protein $(\%)$ & $3.28 \pm 0.47$ & 1.53 & 8.49 \\
\hline Milk fat (\%) & $3.74 \pm 0.98$ & 0.31 & 9.22 \\
\hline Milk lactose, $\%$ & $4.78 \pm 0.33$ & 0.83 & 5.76 \\
\hline $\mathrm{SCC}, \times 1000 \mathrm{~mL}^{-1}$ & $189.00 \pm 661.00$ & 1.00 & 9999.00 \\
\hline MUN (mg dL $\left.{ }^{-1}\right)$ & $19.40 \pm 6.1$ & 0.40 & 39.10 \\
\hline
\end{tabular}


were higher of values than reported in other MUN studies (Broderick and Clayton, 1997; Jonker et al., 1998; Godden and Kelton, 2001; Rajala-Schultz and Saville, 2001; Johnson and Young, 2003; Wattiaux et al., 2005).

Association between MUN and parity: Mean MUN concentration, by parity category is shown in Table 3 . The mean MUN concentration for the third and greater parities was lower $(p<0.0001)$ than the second and third parities, even though the difference was only $0.7 \mathrm{mg} \mathrm{dL}^{-1}$. The results of this study are consistent with some studies (Jonker et al., 1999; Godden and Kelton, 2001), which reported there was a statistically significant but numerically small difference in MUN concentration due to parity. While Canfield et al. (1990) found that there were only minor differences, with no significant association between parity group and MUN concentration. Some studies reported that MUN concentration was higher in first-lactation heifers (Oltner et al., 1985; Godden and Lissemore, 2001; Johnson and Young, 2003). To be concluded, all of the studies reported that higher MUN concentration was estimated in the first and second parities, in contrast to cows in their third and greater lactations. The main reason might be that primiparous cows were still in lean tissue growth and a correspondingly higher efficiency of amino acid utilization. Thus, the deamination of amino acid and urea formation in the liver might be reduced (Oltner et al., 1985). Hojman et al. (2005) got the result that mean MUN concentration was $15.1 \mathrm{mg} \mathrm{dL}^{-1}$ and Jonker et al. (1998) used models to predict changes in MUN concentration due to parity and suggested that the first lactation heifers should have a higher MUN concentration than mature cows. Jonker et al. (1999) reported that, according to $\mathrm{NRC}$ recommendations, target MUN concentration was averaged 16.3, 16.8 and $16.2 \mathrm{mg} \mathrm{dL}^{-1}$ for the first, second and third lactation, respectively. However, the mean MUN concentration in this study was $19.4 \mathrm{mg} \mathrm{dL}^{-1}$. The variability of energy and protein balance could explain differences in the MUN concentration. The forage quality in this study, mainly comprised of sheep grass and corn stalk silage, was lower than the forage in those previous studies. So, the differences in categories and qualities of the forage may account for some of the MUN concentration differences. Further researches to make sure the cause of the higher MUN concentration would be helpful when MUN was regarded as a management tool in China.

Associations between MUN and DIM: There was curvilinear and parallel relationship between MUN concentration and DIM (Fig. 1). The mean concentration of MUN was lower $(\mathrm{p}<0.001)$ during the first 30 DIM category compared with all other DIM categories. Others have shown similar results (Carlsson et al., 1995; Eicher et al., 1999; Godden and Kelton, 2001, Johnson and Young, 2003). The main reason could contribute to differences in DMI, rumen microbial adaptation and rumen absorptive capacity at the beginning stage of lactation. The concentration of MUN reached the

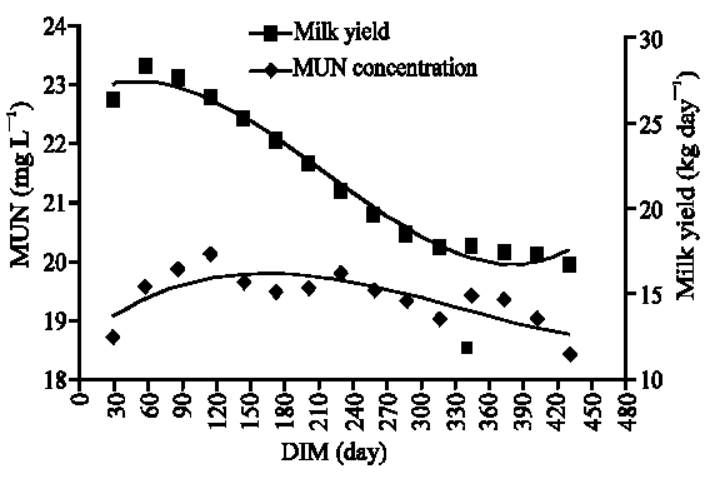

Fig. 1: Least squares means of MUN concentration and milk yield by 30 day DIM category

Table 3: The concentration of MUN by DIM and parity categories

\begin{tabular}{|c|c|c|c|c|c|c|c|c|}
\hline \multirow[b]{2}{*}{ DIM category } & \multicolumn{2}{|c|}{ Lactation 1} & \multicolumn{2}{|c|}{ Lactation 2} & \multicolumn{2}{|c|}{ Lactation 3} & \multicolumn{2}{|l|}{ All } \\
\hline & $\mathrm{N}$ & Mean & $\mathrm{N}$ & Mean & $\mathrm{N}$ & Mean & $\mathrm{N}$ & Mean \\
\hline$<30$ & 596 & 18.99 & 558 & 18.72 & 694 & 18.40 & 1848 & 18.69 \\
\hline $30-60$ & 741 & 19.83 & 654 & 19.50 & 833 & 19.34 & 2228 & 19.55 \\
\hline $90-60$ & 745 & 20.13 & 672 & 19.65 & 833 & 19.73 & 2250 & 19.84 \\
\hline $90-120$ & 730 & $20.93^{\mathrm{A}}$ & 689 & $19.67^{\mathrm{B}}$ & 795 & $19.62^{\mathrm{B}}$ & 2214 & 20.07 \\
\hline $120-150$ & 722 & $20.58^{\mathrm{A}}$ & 714 & $19.40^{\mathrm{B}}$ & 866 & $18.93^{\mathrm{B}}$ & 2302 & 19.59 \\
\hline $150-180$ & 791 & $20.36^{\mathrm{A}}$ & 737 & $19.26^{\mathrm{B}}$ & 893 & $18.76^{\mathrm{B}}$ & 2421 & 19.43 \\
\hline $180-210$ & 848 & $20.38^{\mathrm{A}}$ & 725 & $19.37^{\mathrm{B}}$ & 889 & $18.84^{\mathrm{B}}$ & 2462 & 19.53 \\
\hline $210-240$ & 847 & $20.14^{\mathrm{A}}$ & 708 & $20.27^{\mathrm{A}}$ & 894 & $19.16^{\mathrm{B}}$ & 2449 & 19.82 \\
\hline $240-270$ & 896 & $19.25^{\mathrm{B}}$ & 603 & $20.48^{A}$ & 882 & $19.16^{\mathrm{B}}$ & 2381 & 19.53 \\
\hline $270-300$ & 740 & $19.05^{\mathrm{B}}$ & 522 & $20.02^{\mathrm{Aa}}$ & 771 & $19.13^{b}$ & 2033 & 19.33 \\
\hline $300-330$ & 653 & $18.69^{\mathrm{B}}$ & 414 & $19.88^{\mathrm{Aa}}$ & 570 & $18.83^{b}$ & 1637 & 19.04 \\
\hline $330-360$ & 596 & 19.20 & 333 & 19.97 & 439 & 19.34 & 1368 & 19.43 \\
\hline $360-390$ & 521 & $19.66^{\mathrm{a}}$ & 254 & 19.73 & 325 & $18.57^{\circ}$ & 1100 & 19.35 \\
\hline $390-420$ & 407 & $19.03^{b}$ & 221 & $20.41^{\mathrm{Aa}}$ & 297 & $18.19^{\mathrm{B}}$ & 925 & 19.09 \\
\hline$>420$ & 775 & $18.16^{\mathrm{B}}$ & 396 & $20.21^{A}$ & 625 & $17.83^{\mathrm{B}}$ & 1796 & 18.50 \\
\hline Total/Avg. & 10608 & $19.70^{\mathrm{A}}$ & 8200 & $19.71^{\mathrm{A}}$ & 10606 & $19.00^{\mathrm{B}}$ & 29414 & 19.44 \\
\hline
\end{tabular}

Alphabet in the same row differ; lower-case letters: $p<0.05$; upper-case letter letters: $p<0.01$ 
highest at 90-120 DIM and then was generally lower against after approximately 120 DIM in this study. Arunvipas et al. (2003) also reported that MUN concentration reached the highest at 90-120 DIM. Carlsson et al. (1995) observed that MUN concentration was lowest immediately after calving and reached a peak between the 3rd and 6th month of lactation and slowly declined in later lactation. Godden and Kelton (2001) reported that MUN concentration was generally lowest during the first 60 DIM, higher between 60 and 150 DIM and then were generally lower again after approximately 150 DIM. However, Schepers and Meijer (1998) found that DIM had no effect on mean MUN concentration.

The difference came from the nutritional variables were not statistically independent and the effect of DIM was probably included indirectly through the nutritional factors. From calving to 70-140 days, dry matter intake gradually increases and reaches the highest during 70-140 days. This is the main reason that MUN concentration increases after calving. After earlier lactation, the protein requirement decreases as milk production declines. From the literatures (Broderick and Clayton, 1997; Jonker et al., 1999; Godden and Lissemore, 2001), we can get the result that MUN concentration should also decrease. But MUN concentration did not decline as milk production decreased in some of the herds (data not shown). This suggests the possibility that for those herds, protein may have been overfed in late lactation or the ration contained different amount of rumen degradable protein than earlier lactation (Johnson and Young, 2003).

Association between MUN and milk production: Descriptive information about milk production, stratified by MUN category is shown in (Table 4), there was a positive but nonlinear association between MUN and milk production ( $\mathrm{p}<0.001, \mathrm{Fig} .2$ ). The results were similar to Kung and Huber (1983), Carlsson et al. (1995), Godden and Kelton (2001), Arunvipas et al. (2003), Johnson and Young (2003) and Wattiaux et al. (2005). However, negative association (Ismail et al., 1996) or no relationship (Baker et al., 1995; Carroll et al., 1988) had also been reported. The inconsistent results indicate that MUN concentration is a result of DMI or directly associated in some manner with milk production. The positive nonlinear association between MUN and milk yield may be attributed to increased milk production which resulted from increased DM and total protein intake (Chalupa, 1984; Oldham, 1984; Broderick and Clayton, 1997; Jonker et al., 1999; Godden and Lissemore, 2001). Because the described information of nutritional management was not collected at the cow-level in this study, these hypotheses could not be explored.

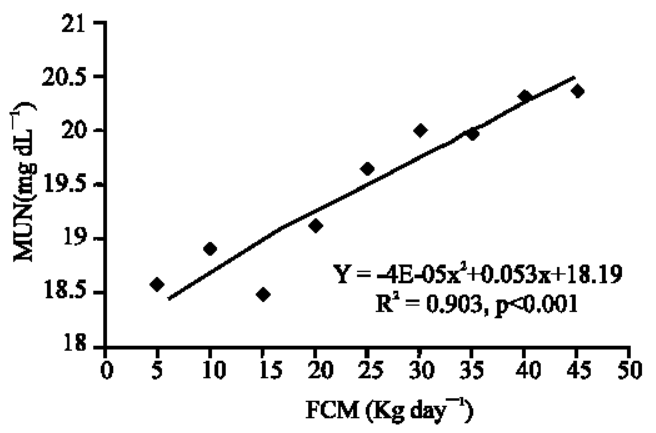

Fig. 2: Least squares means of MUN concentration and milk yield by $5 \mathrm{~kg}$ milk yield category

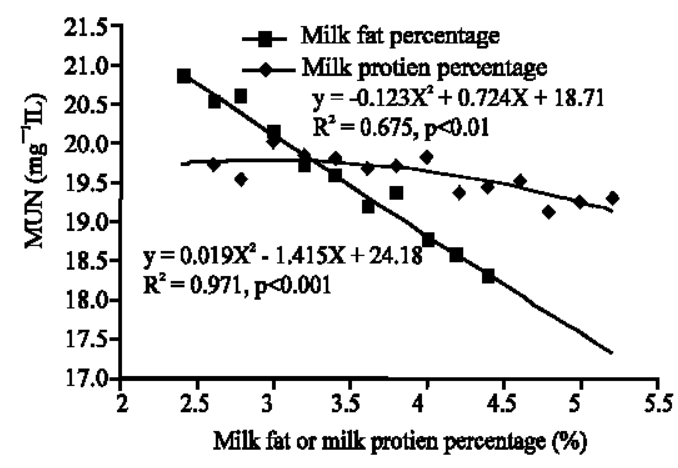

Fig. 3: Least squares means of MUN concentration and milk fat and milk protein percentage category

In this study, MUN concentration increased by $0.044 \mathrm{mg} \mathrm{dL}^{-1}$ as FCM yield increased by $1.0 \mathrm{~kg} \mathrm{day}^{-1}$. Arunvipas et al. (2003) also found that the increment in FCM yield of $1.0 \mathrm{~kg}$ would change the MUN concentration by approximately $0.05 \mathrm{mg} \mathrm{dL}^{-1}$. Wattiaux et al. (2005) reported that MUN concentration increased by $0.06 \mathrm{mg} \mathrm{dL}^{-1}$ per FCM yield increment from $5.0-29.0 \mathrm{~kg}$.

Association between MUN and milk protein percentage: Descriptive information about protein percentage, stratified by MUN category is shown in Table 4. The mixed multivariate regression model of MUN against milk protein percentage is shown in Fig. 3. Equations in this study also suggest that MUN concentration increased, while milk protein percentage decreased $(p<0.01)$.

In this study, a change in milk protein percentage of \pm 1.0 percentage unit would change the estimated mean lactation MUN concentration by approximately $\pm 1.41 \mathrm{mg} \mathrm{dL}^{-1}$.

Higher MUN concentration may be associated with a lower use of dietary $\mathrm{CP}$, leading to decrease nitrogen efficiency. Johnson and Young (2003) also found similar results. While some studies reported that there 
Table 4: Least squares means and SE for milk yield, protein, fat and lactose percentage and SCC by MUN category

\begin{tabular}{|c|c|c|c|c|c|c|c|c|c|c|c|c|c|}
\hline \multirow[b]{2}{*}{ MUN } & \multirow[b]{2}{*}{$\mathrm{N}$} & \multicolumn{2}{|c|}{ Milk (kg) } & \multicolumn{2}{|c|}{ FCM (kg) } & \multicolumn{2}{|c|}{ Protein $(\%)$} & \multicolumn{2}{|c|}{ Fat (\%) } & \multicolumn{2}{|c|}{$\mathrm{SCC} \times 1000 \mathrm{~mL}^{-1}$} & \multicolumn{2}{|c|}{ Lactose (\%) } \\
\hline & & Mean & SE & Mean & SE & Mean & SE & Mean & $\mathrm{SE}$ & Mean & $\mathrm{SE}$ & Mean & $\mathrm{SE}$ \\
\hline$<6.0$ & 228 & 19.45 & 0.65 & 17.60 & 0.61 & 3.39 & 0.08 & 3.40 & 0.04 & 590.13 & 94.15 & 4.65 & 0.03 \\
\hline $6.01-8.0$ & 357 & 20.82 & 0.48 & 18.45 & 0.43 & 3.41 & 0.06 & 3.23 & 0.02 & 199.28 & 40.70 & 4.77 & 0.02 \\
\hline $8.01-10.0$ & 802 & 20.02 & 0.31 & 18.84 & 0.31 & 3.61 & 0.04 & 3.38 & 0.02 & 230.14 & 31.08 & 4.74 & 0.02 \\
\hline $10.01-12.0$ & 1547 & 20.28 & 0.22 & 19.62 & 0.22 & 3.83 & 0.03 & 3.41 & 0.01 & 144.00 & 13.35 & 4.78 & 0.01 \\
\hline $12.01-14.0$ & 2420 & 21.46 & 0.18 & 20.77 & 0.18 & 3.85 & 0.02 & 3.37 & 0.01 & 161.40 & 11.70 & 4.78 & 0.01 \\
\hline $14.01-16.0$ & 3250 & 22.23 & 0.15 & 21.50 & 0.16 & 3.81 & 0.02 & 3.33 & 0.01 & 155.07 & 9.71 & 4.80 & 0.01 \\
\hline $16.01-18.0$ & 3631 & 22.57 & 0.15 & 21.67 & 0.15 & 3.77 & 0.02 & 3.28 & 0.01 & 191.33 & 12.02 & 4.80 & 0.01 \\
\hline $18.01-20.0$ & 3656 & 23.01 & 0.15 & 21.93 & 0.15 & 3.74 & 0.02 & 3.26 & 0.01 & 198.71 & 11.36 & 4.79 & 0.01 \\
\hline $20.01-22.0$ & 3454 & 23.40 & 0.15 & 22.40 & 0.15 & 3.73 & 0.02 & 3.26 & 0.01 & 220.04 & 13.18 & 4.80 & 0.01 \\
\hline $22.01-24.0$ & 3120 & 23.80 & 0.16 & 22.61 & 0.16 & 3.68 & 0.02 & 3.24 & 0.01 & 175.03 & 10.75 & 4.80 & 0.01 \\
\hline $24.01-26.0$ & 2393 & 23.72 & 0.19 & 22.49 & 0.19 & 3.67 & 0.02 & 3.24 & 0.01 & 178.98 & 11.04 & 4.77 & 0.01 \\
\hline $26.01-28.0$ & 1737 & 23.42 & 0.23 & 22.26 & 0.23 & 3.69 & 0.02 & 3.23 & 0.01 & 166.51 & 13.15 & 4.76 & 0.01 \\
\hline $28.01-30.0$ & 1192 & 24.10 & 0.28 & 22.86 & 0.28 & 3.73 & 0.03 & 3.26 & 0.01 & 183.35 & 17.08 & 4.73 & 0.01 \\
\hline $30.01-32.0$ & 693 & 23.41 & 0.38 & 21.66 & 0.38 & 3.65 & 0.04 & 3.25 & 0.02 & 208.20 & 24.34 & 4.72 & 0.01 \\
\hline $32.01-34.0$ & 375 & 23.73 & 0.50 & 22.25 & 0.50 & 3.88 & 0.06 & 3.23 & 0.02 & 267.48 & 41.67 & 4.74 & 0.02 \\
\hline $34.01-36.0$ & 365 & 22.30 & 0.54 & 20.44 & 0.53 & 3.62 & 0.07 & 3.25 & 0.04 & 222.38 & 34.36 & 4.75 & 0.02 \\
\hline$>36.0$ & 194 & 20.82 & 0.72 & 19.81 & 0.71 & 3.77 & 0.08 & 3.20 & 0.04 & 439.03 & 67.65 & 4.76 & 0.02 \\
\hline Total/avg. & 29414 & 22.69 & 0.05 & 21.66 & 0.05 & 3.74 & 0.01 & 3.28 & 0.003 & 189.69 & 3.86 & 4.78 & 0.002 \\
\hline
\end{tabular}

Table 5: The concentration of MUN by milk yield and protein percentage categories

\begin{tabular}{|c|c|c|c|c|c|c|c|c|c|}
\hline \multirow[b]{2}{*}{ Milk categories } & \multicolumn{3}{|c|}{$<3.00 \%$} & \multicolumn{3}{|c|}{$3.01-3.20 \%$} & \multicolumn{3}{|c|}{$>3.20 \%$} \\
\hline & $\mathrm{N}$ & MUN (mg dL $\left.{ }^{-1}\right)$ & SE & $\mathrm{N}$ & MUN (mg dL $\left.{ }^{-1}\right)$ & SE & $\mathrm{N}$ & MUN (mg dL $\left.{ }^{-1}\right)$ & $\mathrm{SE}$ \\
\hline $5.0-10.0$ & 258 & $21.49^{\mathrm{Aa}}$ & 0.43 & 218 & $20.18^{\mathrm{Ab}}$ & 0.40 & 1611 & $18.43^{\mathrm{B}}$ & $\overline{0.16}$ \\
\hline $10.1-15.0$ & 401 & $19.29^{\mathrm{A}}$ & 0.30 & 403 & $18.02^{\mathrm{B}}$ & 0.29 & 1948 & $17.92^{\mathrm{B}}$ & 0.13 \\
\hline $15.1-20.0$ & 976 & $19.67^{\mathrm{Aa}}$ & 0.19 & 768 & $19.00^{b}$ & 0.22 & 2418 & $18.81^{\mathrm{B}}$ & 0.12 \\
\hline $20.1-25.0$ & 1585 & $20.25^{\mathrm{A}}$ & 0.15 & 1040 & $19.23^{\mathrm{B}}$ & 0.18 & 3483 & $19.25^{\mathrm{B}}$ & 0.10 \\
\hline $25.1-30.0$ & 1872 & $20.38^{\mathrm{A}}$ & 0.14 & 1186 & $20.34^{\mathrm{A}}$ & 0.17 & 2281 & $19.49^{\mathrm{B}}$ & 0.12 \\
\hline $30.1-35.0$ & 1608 & $20.52^{\mathrm{Aa}}$ & 0.15 & 772 & $19.94^{b}$ & 0.21 & 1069 & $19.53^{\text {B }}$ & 0.18 \\
\hline $35.1-40.0$ & 842 & 20.53 & 0.19 & 317 & 20.20 & 0.33 & 320 & 20.19 & 0.32 \\
\hline $40.1-45.0$ & 349 & $21.16^{\mathrm{a}}$ & 0.28 & 89 & $19.80^{b}$ & 0.47 & 61 & $20.62^{\mathrm{a}}$ & 0.82 \\
\hline$\geq 45.0$ & 124 & $22.19^{a}$ & 0.43 & 13 & 21.25 & 1.00 & 15 & $19.27^{b}$ & 0.15 \\
\hline
\end{tabular}

Alphabet in the same row differ; lower-case letters: $\mathrm{p}<0.05$; upper-case letter letters: $\mathrm{p}<0.01$

was either no relationship between milk protein percentage and MUN (Broderick and Clayton, 1997) or a negative, nonlinear association (Godden and Kelton, 2001).

Nelson (1996) suggested that MUN concentration should be $12-16 \mathrm{mg} \mathrm{dL}^{-1}$ if protein degradability fractions and energy were most likely balanced when milk protein was $3.0-3.2 \%$. Whereas Kohn et al. (2002) recommended that MUN concentration should be $10-12 \mathrm{mg} \mathrm{dL}^{-1}$ on herd-level in the Intermountain West of America in order to avoid the possibility of overfeeding protein or underestimating protein degradability of the high quality alfalfa hay. In this study, cow-level mean MUN concentration for each category of milk protein percentage and milk yield was within this range for Holsteins, except when milk production was very high, then MUN concentration was higher than the range. The forage in this study were in different categories and qualities than were the forage in the t-studies of Nelson (1996) and Kohn et al. (2002), we can not compare the concentration of MUN with each other. More researches were needed to accomplish in order to build up a recommended range of MUN concentration in China. The concentration of MUN, categorized by milk yield and protein percentage categories of $\leq 3.0,3.01-3.2$ and $>3.2 \%$ is shown in Table 5. The concentration of MUN was higher $(\mathrm{p}<0.001$ ) for milk protein $<3.0 \%$ than $>3.2 \%$, when milk yields ranged from $5.0-35.0 \mathrm{~kg}$. There was no difference between milk protein $<3.0 \%$ and $>3.2 \%$ for milk yields ranging from $35.1-45.0 \mathrm{~kg}$ day $^{-1}$. In one of similar studies, Johnson and Young (2003) reported that MUN concentration was lower for cows of milk protein $>3.2 \%$ than the grouping of $<3.2 \%$ milk protein for milk yields ranging from $27.3-63.6 \mathrm{~kg}$ day $^{-1}$. From these results, we could reach the conclusion that MUN concentration and milk protein percentage should be synchronously considered, when we evaluate the balance of metabolic energy and nitrogen in the ration.

Association between MUN and milk fat percentage: An inverse relationship between MUN categories and milk fat percentage was observed in these data $(\mathrm{p}<0.001$, Fig. 3). Within the normal physiological range of milk fat percentages, MUN concentration change was very small, but as milk fat percentage increased MUN concentration decreased. A negative and nonlinear association between milk fat percentage and MUN was also reported by Broderick and Clayton (1997), Godden and Kelton (2001) 
and Johnson and Young (2003). In this study, a change in milk fat of \pm 1.0 percentage unit would change the estimated mean lactation MUN concentration by approximately $\pm 1.42 \mathrm{mg} \mathrm{dL}^{-1}$. While Jonker et al. (1998) predicted that a change in milk fat of \pm 1.0 percentage unit would change the estimated mean lactation MUN concentration by approximately $\pm 3.40 \mathrm{mg} \mathrm{dL}^{-1}$. The relationship between milk fat percentage and MUN may be an indirect result of nutritional variables or a direct negative effect of milk fat percentage on MUN (Carlsson and Bergstrom, 1994).

Association between MUN and SCC: There was no significant negative nonlinear association between MUN and SCC with a mixed multivariate regression model ( $\mathrm{p}=0.147$, Fig. 4). Eicher et al. (1999) also reported no significant association of SCC on MUN. Godden and Kelton (2001) and Johnson and Young (2003) reported a slightly negative relationship between MUN and linear score. Ng-Kwai-Hang et al. (1985) reported a positive association between cow-level SCC and true protein content and also reported a small but significant positive association between SCC and milk NPN levels (which includes urea). Although, a negative relationship between cow-level SCC and MUN was observed in some studies, MUN data should be interpreted at the group-level and not the individual cow

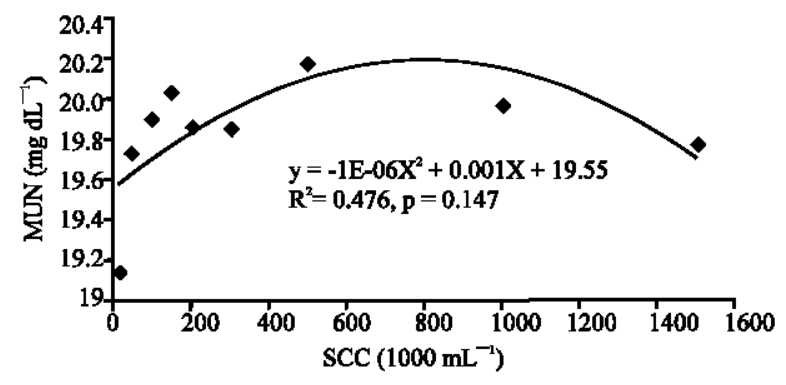

Fig. 4: Least squares means of MUN concentration and milk yield by $200(\times 1000)$ SCC category

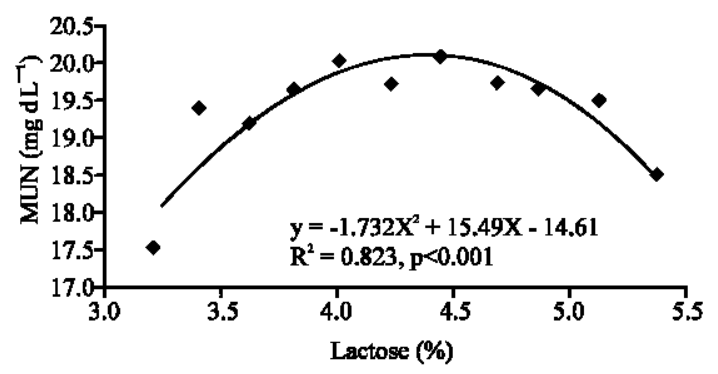

Fig. 5: Least squares means of MUN concentration and milk yield by $2 \%$ lactose category level (Broderick and Clayton, 1997; Cannas et al., 1998; Kolver and MacMillan, 1993; Oltner et al., 1985; Schepers and Meijer, 1998). Therefore, unless a large proportion of cows in the group or herd have very high $\mathrm{SCC}$, then the herd average MUN should not be greatly affected by SCC. There was positive association between SCC and mastitis infection because recovery system would produce more leucocyte to kill these bacteria, when the udder was infected. Most bacteria, actinomycetes and fungi can produce urease, which would degrade urea in the milk to ammonia. With the permeability of mammary gland increasing, more urea would come into milk from blood. As a result, a positive or negative correlation between MUN and SCC lies on the competing effect of the permeability of galactophore and the degradation of urea.

Association between MUN and Lactose: The test day average lactose percentage across parities was $4.78 \%$. Results from this study showed that there was a statistically significant $(\mathrm{p}<0.001$, Fig. 5) association between lactose percentage and MUN. The concentration of MUN reached the peak when lactose percentage was $4.2 \%$. The relationship between lactose and MUN may be an indirect result of milk yield. It is because of lactose synthesis regulating the volume of milk secreted. It indicates that lactose percentage and MUN concentration are indicators of metabolic disorders and physiological imbalance, which in turn affect the reproductive and health status of a given animal (Miglior et al., 2006).

\section{CONCLUSION}

The mean MUN concentration was $19.4 \mathrm{mg} \mathrm{dL}^{-1}$ and lowest in the third and greater parities. The concentration of MUN reached the highest at 90-120 DIM, and then was generally lower against after approximately 120 DIM. A positive relationship existed between MUN and milk production, while negative relationships with milk protein and milk fat percentage were observed. Based on the results of this study, MUN concentration should be interpreted in association with parity, DIM, milk production and composition when it was regarded as a management tool to evaluate the efficiency of nitrogen utilization for dairy cows in China.

\section{ACKNOWLEDGEMENTS}

This research was financed by the earmarked fund for Modern Agro-industry Technology Research System and the earmarked fund for Public Industry, Ministry of Agriculture, P.R. China. 


\section{REFERENCES}

Arunvipas, P., I.R. Dohoo, J.A. van Leeuwen and G.P. Keefe, 2003. The effect of non-nutritional factors on milk urea nitrogen levels in dairy cows in Prince Edward Island. Prev. Vet. Med., 59: 83-93.

Baker, L.D., J.D. Ferguson and W. Chalupa, 1995. Reponses in urea and true protein milk to different feeding schemes for dairy cows. J. Dairy Sci., 78: 2424-2434.

Broderick, G.A. and M.K. Clayton, 1997. A statistical evaluation of animal and nutritional factors influencing concentrations of milk urea nitrogen. J. Dairy Sci., 80: 2964-2971.

Canfield, R.W., C.J. Sniffen and W.R. Bulter, 1990. Effects of excess degradable protein on postpartum reproduction and energy balance in dairy cattle. J. Dairy Sci., 73: 2342-2349.

Cannas, A., A. Pes, R. Mancuso, B. Vodret and A. Nudda, 1998. Effect of dietary energy and protein concentration on the concentration of milk urea nitrogen in dairy ewes. J. Dairy Sci., 81: 499-508.

Carlsson, J. and J. Bergstrom. 1994. The diurnal variation of urea in cow's milk and how milk fat content, storage and preservation affects analysis by a flow injection technique. Acta. Vet. Scand., 34: 67-77.

Carlsson, J., J. Bergsrtom and B. Pehrson, 1995. Variations with breed, age, season, yield, stage of lactation and herd in the concentration of urea in bulk milk and individual cows milk. Acta. Vet. Scand., 36: 245-254.

Carroll, D.J., B.A. Barton, G.W. Anderson and R.D. Smith, 1988. Influence of protein intake and feeding strategy on reproductive performance of dairy cows. J. Dairy Sci., 71: 3470-3481

Chalupa, W., 1984. Discussion of protein symposium. J. Dairy Sci., 67: 1134-1146.

Eicher, R., E. Bouchard and M. Bigras-Poulin, 1999. Factors affecting milk urea nitrogen and protein concentrations in Quebec dairy cows. Prev. Vet. Med., 39: 53-63.

Godden, S.M. and D.F. Kelton, 2001. Milk uera testing as a tool to monitor reproductive performance in ontario dairy herds. J. Dairy Sci., 84: 1397-1406.

Godden, S.M. and K.D. Lissemore, 2001. Factors associated with milk urea concentrations in Ontario dairy cows. J. Dairy Sci., 84: 107-114.

Hof, G., M.D. Vervoorn and P.J. Lenaers, 1997. Milk urea nitrogen as a tool to monitor the protein nutrition of dairy cows. J. Dairy Sci., 80: 3333-3340.

Hojman, D., M. Gips and E. Ezra, 2005. Associations between live body weight and milk urea concentration in Holstein cows. J. Dairy Sci., 88: $580-584$.
Ismail, A., K. Diab and J.K. Hillers, 1996. Effect of selection for milk yield and dietary energy on yield traits, bovine somatotropin and plasma urea nitrogen in dairy cows. J. Dairy Sci., 79: 682-688.

Johnson, R.G. and A.J. Young, 2003. The association between milk urea nitrogen and DHI production variables in western commercial dairy herds. J. Dairy Sci., 86: 3008-3015.

Jonker, J.S., R.A. Kohn and R.A. Erdman, 1998. Using milk urea nitrogen to predict nitrogen excretion and utilization efficiency in lactating dairy cows. J. Dairy Sci., 81: 2681-2692.

Jonker, J.S., R.A. Kohn and R.A. Erdman, 1999. Milk urea nitrogen target concentration for lactating dairy cows fed according to national research council recommendations. J. Dairy Sci., 82: 1261-1273.

Kohn, R.A., K.F. Kalscheur and E. Russek-Cohen, 2002. Evaluation of models to estimate urinary nitrogen and expected milk urea nitrogen. J. Dairy Sci., 85: $227-233$.

Kolver, E.S. and K.L. MacMillan, 1993. Short term changes in selected metabolites in pasture fed dairy cows during peak lactation. Proc. N. Z. Soc. Anim. Prod., 53: 77-81.

Kung, Jr. L. and J.T. Huber, 1983. Performance of high producing cows in early lactation fed protein of varying amounts, sources and degradability. J. Dairy Sci., 66: 227-234.

Miglior, F., A. Sewalem, J. Jamrozik, D.M. Lefebvre and R.K. Moore, 2006. Analysis of milk urea nitrogen and lactose and their effect on longevity in Canadian dairy cattle. J. Dairy Sci., 89: 4886-4894.

Miglior, F., W. Gong, Y. Wang, G.J. Kistemaker, A. Sewalem and J. Jamrozik, 2009. Short communication: Genetic parameters of production traits in Chinese Holsteins using a random regression test-day model. J. Dairy Sci., 92: 4697-4706.

NRC, 2001. Nutrient Requirements of Dairy Cattle. 7th Rev. Edn., National Academy Press, Washington, DC., pp: 333.

Nelson, A., 1996. Practical applications of MUN analyses. Bovine Pract., 29: 85-95.

Ng-Kwai-Hang, K.F., J.F. Hayes, J.E. Moxley and H.G. Monardes, 1985. Percentages of protein and nonprotein nitrogen with varying fat and somatic cells in bovine milk. J. Dairy Sci., 68: 1257-1262.

Oldham, J.D., 1984. Protein-energy interrelationships in dairy cows. J. Dairy Sci., 67: 1090-1114.

Oltner, R., M. Emanuelson and H. Wiktorsson, 1985. Urea concentrations in milk in relation to milk yield, live weight, lactation umber and amount and composition of feed given to dairy cows. Livest. Prod. Sci., 12: 47-57. 
Rajala-Schultz, P.J. and W.J.A. Saville, 2001. Association between milk urea nitrogen and fertility in Ohio dairy cows. J. Dairy Sci., 84: 482-489.

Roseler, D.K., J.D. Ferguson, C.J. Sniffen and J. Herrema. 1993. Dietary protein degradability effects on plasma and milk urea nitrogen and milk nonprotein nitrogen in Holstein cows. J. Dairy Sci., 76: 525-534.

Schepers, A. J. and R.G. Meijer, 1998. Evaluation of the utilization of dietary nitrogen by dairy cows based on urea concentration in milk. J. Dairy Sci., 81: 579-584.
Wattiaux, M.A. and K.L. Karg, 2004a. Protein level for alfalfa and corn silage-based diets: I. Lactational response and Milk Urea Nitrogen. J. Dairy Sci., 81: 3480-3491.

Wattiaux, M.A. and K.L. Karg, 2004b. Protein level for alfalfa and corn silage-based diets: II. Nitrogen balance and manure characteristics. J. Dairy Sci., 87: 3492-3502.

Wattiaux, M.A., E.V. Nordheim and P. Crump, 2005. Statistical evaluation of factors and interactions affecting dairy herd improvement milk urea nitrogen in commercial midwest dairy herds. J. Dairy Sci., 88: 3020-3035. 